\title{
Review of the treatment of psoriatic arthritis with biological agents: choice of drug for initial therapy and switch therapy for non-responders
}

This article was published in the following Dove Press journal:

Open Access Rheumatology: Research and Reviews

2 March 2017

Number of times this article has been viewed

\author{
Salvatore D'Angelo' \\ Giuseppina Tramontano' \\ Michele Gilio' \\ Pietro Leccese' \\ Ignazio Olivieri' ${ }^{1,2}$
}

'Rheumatology Institute of Lucania (IRel) - Rheumatology Department of Lucania, San Carlo Hospital of Potenza and Madonna delle Grazie Hospital of Matera, Potenza and Matera, ${ }^{2}$ Basilicata Ricerca Biomedica (BRB) Foundation, Potenza, Italy
Correspondence: Salvatore D'Angelo Rheumatology Institute of Lucania (IRel) - Rheumatology Department of Lucania, San Carlo Hospital of Potenza and Madonna delle Grazie Hospital of Matera, Potenza and Matera, Via Potito Petrone snc, 85100 Potenza, Italy

Tel +3909716I3072

Fax +390971613036

Email saldangelo@katamail.com

\begin{abstract}
Psoriatic arthritis (PsA) is a heterogeneous chronic inflammatory disease with a broad clinical spectrum and variable course. It can involve musculoskeletal structures as well as skin, nails, eyes, and gut. The management of PsA has changed tremendously in the last decade, thanks to an earlier diagnosis, an advancement in pharmacological therapies, and a wider application of a multidisciplinary approach. The commercialization of tumor necrosis factor inhibitors (adalimumab, certolizumab pegol, etanercept, golimumab, and infliximab) as well as interleukin (IL)-12/23 (ustekinumab) and IL-17 (secukinumab) inhibitors is representative of a revolution in the treatment of PsA. No evidence-based strategies are currently available for guiding the rheumatologist to prescribe biological drugs. Several international and national recommendation sets are currently available with the aim to help rheumatologists in everyday clinical practice management of PsA patients treated with biological therapy. Since no specific biological agent has been demonstrated to be more effective than others, the drug choice should be made according to the available safety data, the presence of extra-articular manifestations, the patient's preferences (e.g., administration route), and the drug price. However, future studies directly comparing different biological drugs and assessing the efficacy of treatment strategies specific for PsA are urgently needed.
\end{abstract}

Keywords: psoriatic arthritis, treatment, biological drugs, TNF inhibitors, ustekinumab, secukinumab

\section{Introduction}

Psoriatic arthritis (PsA) is a heterogeneous chronic inflammatory disease with a broad spectrum of clinical features and courses. ${ }^{1}$ In order to underline the great heterogeneity of clinical manifestations and the importance of each feature in therapeutic strategies, the term "psoriatic disease" has been proposed. ${ }^{2}$ PsA manifestations can involve not only musculoskeletal structures (joints, entheses, synovial sheaths of tendons, axial skeleton), together with the skin and nails, but also gut and eyes. ${ }^{3-5}$ In addition, in patients with PsA or psoriasis there is a higher risk of obesity, insulin resistance, type 2 diabetes, metabolic syndrome, hypertension, hyperlipidemia, and cardiovascular disease than in the general population. ${ }^{6}$ In the past, PsA was considered a mild disease. On contrary, in the last decades, much attention has been paid to the erosive and deforming features of PsA (40\%-60\% of patients), which are often the cause of diminished quality of life (QoL) and functional impairment. ${ }^{7-9}$

PsA treatment, quite insufficient until some years ago, has been impressively improved in the last 3 half-decades. Thanks to a better understanding in PsA 
pathogenesis, new biotechnological drugs have been developed. Such drugs are able to ameliorate signs and symptoms of inflammation as well as to inhibit joint damage in peripheral joints with an improvement in QoL and functional status. ${ }^{1}$ Therefore, it is now possible to efficaciously modify the course of the disease. ${ }^{10,11}$ The current therapeutic goals consist of obtaining the remission of symptoms and preventing the appearance of damage in the early stage of PsA or blocking PsA progression in the established cases.

In order to help rheumatologists in everyday clinical practices, several international and national recommendation sets have been developed for PsA management, such as Group for Research and Assessment of Psoriasis and Psoriatic Arthritis (GRAPPA) $^{12}$ and European League Against Rheumatism (EULAR $)^{13}$ recommendations, all of them suggesting that biological drugs therapies should be reserved for patients with active disease refractory to conventional synthetic drugs or expected to have poor prognosis. Definitions of active disease vary but they generally include more than 1 tender and inflamed joint and/or tender enthesis point and/or dactylitis and/or presence of inflammatory back pain. ${ }^{14}$

\section{Current non-biological pharmacological treatment}

The main non-biological pharmacological treatment categories for PsA are nonsteroidal anti-inflammatory drugs (NSAIDs), corticosteroids, and conventional synthetic disease-modifying antirheumatic drugs (csDMARDs).

NSAIDs are used as symptomatic drugs since they do not seem to have effects in preventing joint destruction progression. They are mainly used in mild forms of peripheral arthritis, enthesitis, and dactylitis, while they have no effects on psoriasis.

Corticosteroids can be used both as local injection (especially in monoarthritis or oligoarthritis, dactylitis, or enthesitis) and orally, although their systemic use is not supported by evidence. Routine use of systemic corticosteroids is not recommended, but some patients require corticosteroids for rescue therapy. In these cases, clinicians should pay attention due to theoretical risk of rebound/worsening of psoriasis on withdrawal of the drug.

csDMARDs are used in peripheral involvement, even if there is no evidence that they prevent or significantly decrease the evolution of structural joint damage. ${ }^{15}$ Their use for axial disease is not supported by evidence. Among csDMARDs, methotrexate (MTX), leflunomide (LEF), cyclosporine (CsA), and sulfasalazine (SSZ) are used. MTX, LEF, and CsA have effects both on musculoskeletal and cutaneous diseases, whereas SSZ has effect on arthritis only. Their use in mild disease is preferred because of their low cost. ${ }^{16}$
Apremilast, a new targeted synthetic DMARDs, is a phosphodiesterase 4 inhibitor inducing the suppression of several inflammation mediators including interleukin (IL)-2, IL-12, interferon- $\gamma$, tumor necrosis factor (TNF)- $\alpha$, and inducible nitric oxide synthase. It is given orally at the dose of $30 \mathrm{mg}$ twice a day. ${ }^{17,18}$ Its efficacy and safety in PsA have been evaluated through 4 multicentric, randomized trials compared to placebo in patients who have failed other biological drugs (PALACE1, PALACE2, PALACE3) $)^{19-21}$ or csDMARDs (PALACE4). ${ }^{22}$ At 52 weeks, results of the 4 trials showed efficacy of apremilast in peripheral arthritis, enthesitis, dactylitis, and functional impairment. Apremilast has been recently approved by both the United States Food and Drug Administration (FDA) and European Medicines Agency (EMA) for the treatment of active PsA patients.

\section{Biological drugs}

The development of biological agents have opened new horizons since it is now possible to better control signs and symptoms of inflammation, improve QoL and functional status, and inhibit the progression of structural damage in peripheral joints. The biological agents available for PsA treatment include anti-TNF- $\alpha$ (etanercept [ETN], infliximab [INF], adalimumab [ADA], golimumab [GOL], and certolizumab pegol [CZP]; INF and ETN biosimilars), antiIL-17 (secukinumab [SEC]) and anti-IL-12/23 (ustekinumab [UST]) (Tables 1 and 2).

INF is a chimeric (mouse-human) monoclonal antibody that binds both to soluble and membrane-bound TNF- $\alpha$. It is given intravenously at a dosage of $5 \mathrm{mg} / \mathrm{kg}$ body weight over a period of at least 2 hours at weeks 0,2 , and 6 and every 6-8 weeks thereafter. INF efficacy has been mainly evaluated in the IMPACT 2 trial enrolling 200 patients with active PsA despite the use of previous csDMARDs or NSAIDs. ${ }^{23}$ At week 24, compared with placebo, INFtreated patients had significantly better response rates for ACR 20 (54\% vs 16\%), Psoriatic Arthritis Response Criteria (PsARC) (70\% vs 32\%), and Psoriasis Area and Severity Index (PASI) 75 (60\% vs 1\%), and there was an improvement in dactylitis (12\% vs 34\%) and enthesopathy (20\% vs $37 \%$ ) too. Moreover, disability and QoL measures were also significantly improved. INF was generally well tolerated, with a similar incidence of adverse events in each group. ${ }^{23}$ Long-term safety was confirmed by a 2-year study showing serious adverse events in $5 \%$ of the patients. ${ }^{24} \mathrm{At}$ week 54, INF was able to inhibit radiographic progression as measured by PsA-modified Sharp (mean changes from baseline score were -0.94 in the INF group and +0.53 in the placebo group). ${ }^{25}$ 
ETN is a soluble TNF receptor p75-IgG1 fusion protein. It is given subcutaneously, either as a single $50 \mathrm{mg}$ weekly dose or as two $25 \mathrm{mg}$ doses. ETN efficacy in PsA has been assessed by Mease et al in a trial enrolling 205 patients with

Table I Biological drugs currently licensed for PsA

\begin{tabular}{|c|c|c|c|}
\hline Molecule & Mechanism of action & Route & Dosage \\
\hline Infliximab & $\begin{array}{l}\text { Chimeric monoclonal } \\
\text { antibody against TNF- } \alpha\end{array}$ & IV & $\begin{array}{l}5 \mathrm{mg} / \mathrm{kg} \text { at weeks } 0, \\
2 \text {, and } 6 \text { and every } \\
6-8 \text { weeks }\end{array}$ \\
\hline Etanercept & $\begin{array}{l}\text { Soluble TNF receptor } \\
\text { p75-lgG I fusion protein }\end{array}$ & SC & $50 \mathrm{mg} /$ week \\
\hline Adalimumab & $\begin{array}{l}\text { Fully human anti-TNF- } \alpha \\
\text { monoclonal antibody }\end{array}$ & SC & $\begin{array}{l}40 \mathrm{mg} \text { every } \\
2 \text { weeks }\end{array}$ \\
\hline Golimumab & $\begin{array}{l}\text { Fully human } \lg G \mathrm{Ik} \\
\text { anti-TNF- } \alpha \text { antibody }\end{array}$ & SC & $50 \mathrm{mg} / \mathrm{month}$ \\
\hline $\begin{array}{l}\text { Certolizumab } \\
\text { pegol }\end{array}$ & $\begin{array}{l}\text { Fab fragment of anti- } \\
\text { TNF- } \alpha \text { monoclonal } \\
\text { antibody }\end{array}$ & SC & $\begin{array}{l}400 \mathrm{mg} \text { at } 0,2 \text {, } \\
\text { and } 4 \text { weeks and } \\
\text { then } 200 \mathrm{mg} \text { every } \\
2 \text { weeks }\end{array}$ \\
\hline Ustekinumab & $\begin{array}{l}\text { Fully human IgGI } \\
\text { monoclonal antibody } \\
\text { against the shared P40 } \\
\text { subunit of human IL-12 } \\
\text { and IL-23 }\end{array}$ & SC & $\begin{array}{l}45 \mathrm{mg} \text { at weeks } \\
0 \text { and } 4 \text { and then } \\
\text { every } 12 \text { weeks } \\
(90 \mathrm{mg} \text { if weight } \\
>100 \mathrm{~kg})\end{array}$ \\
\hline Secukinumab & $\begin{array}{l}\text { Monoclonal antibody } \\
\text { against IL-I7A }\end{array}$ & SC & $\begin{array}{l}\text { I } 50 \text { (or } 300) \mathrm{mg} \\
\text { at weeks } 0, \mathrm{I}, 2 \text {, } \\
3 \text {, and } 4 \text { and every } \\
4 \text { weeks thereafter } \\
\text { or directly } \\
150 \mathrm{mg} / \mathrm{month}\end{array}$ \\
\hline
\end{tabular}

Abbreviations: PsA, psoriatic arthritis; TNF, tumor necrosis factor; IV, intravenous; SC, subcutaneous; IL, interleukin. active PsA despite previous use of NSAIDs. ${ }^{26} \mathrm{~A}$ significant improvement was observed in patients treated with ETN compared to placebo for ACR 20 (59\% vs 15\%) and PsARC ( $72 \%$ vs $31 \%$ ) at 12 weeks, and for PASI 75 (23\% vs 3\%) at 24 weeks. Health Assessment Questionnaire (HAQ) decreased significantly in the ETN group. ${ }^{26} \mathrm{~A}$ good response was also obtained in inhibiting radiographic disease progression: at 12 months, the mean annualized rate of change in the modified total Sharp score was -0.03 in the ETN group compared with +1.00 in the placebo group. ETN was well tolerated without substantial differences in frequency of adverse events and infections compared to placebo. ${ }^{26}$ Efficacy and safety of ETN have been confirmed in several open long-term studies. ${ }^{27,28}$

ADA is a fully human anti-TNF- $\alpha$ monoclonal antibody. It is administered subcutaneously at the dosage of $40 \mathrm{mg}$ every other week. ADEPT trial assessed its efficacy in PsA patients with moderately to severely active disease despite the use of previous NSAIDs. ${ }^{29}$ At 24 weeks, significant data were obtained for ACR 20 ( $57 \%$ vs $15 \%$ ), PsARC ( $60 \%$ vs $23 \%$ ), and PASI 75 (59\% vs $1 \%$ ) compared with placebo, as well as disability and QoL measures. ADA was well tolerated with a similar incidence of adverse events and infections in the placebo group. ${ }^{29}$ Such data were confirmed by a 2 -year open-label extension study. ${ }^{30}$ As far as radiographic progression is concerned, at week 48 the mean change from baseline in the modified Sharp score was 0.1 in patients receiving ADA and 1.0 in those receiving placebo for 24 weeks followed by ADA for 24 weeks. $^{31}$

Table 2 Currently approved biological drugs for PsA: efficacy data from registrative trials

\begin{tabular}{|c|c|c|c|c|}
\hline Molecule & $\begin{array}{l}\text { PASI } 75 \\
\text { (at week 24) }\end{array}$ & $\begin{array}{l}\text { ACR } 20 \\
\text { (at week 24) }\end{array}$ & $\begin{array}{l}\text { ACR } 50 \\
\text { (at week 24) }\end{array}$ & $\begin{array}{l}\text { ACR } 70 \\
\text { (at week 24) }\end{array}$ \\
\hline $\begin{array}{l}\text { Infliximab }{ }^{23} \\
(5 \mathrm{mg} / \mathrm{kg} \text { at weeks } 0,2,6,14 \text {, and } 22)\end{array}$ & $\begin{array}{l}60 \% \\
(1 \%)\end{array}$ & $\begin{array}{l}54 \% \\
(16 \%)\end{array}$ & $\begin{array}{l}41 \% \\
(4)\end{array}$ & $\begin{array}{l}27 \% \\
(2 \%)\end{array}$ \\
\hline $\begin{array}{l}\text { Etanercept }^{26} \\
(25 \mathrm{mg} \text { twice weekly) }\end{array}$ & $\begin{array}{l}23 \% \\
(3 \%)\end{array}$ & $\begin{array}{l}59 \% * \\
(15 \% *)\end{array}$ & - & - \\
\hline $\begin{array}{l}\text { Adalimumab }^{29} \\
\text { ( } 40 \text { mg every } 2 \text { weeks) }\end{array}$ & $\begin{array}{l}59 \% \\
(1 \%)\end{array}$ & $\begin{array}{l}57 \% \\
(15 \%)\end{array}$ & $\begin{array}{l}39 \% \\
(6 \%)\end{array}$ & $\begin{array}{l}23 \% \\
(1 \%)\end{array}$ \\
\hline $\begin{array}{l}\text { Golimumab }^{32} \\
\text { ( } 50 \text { mg every } 4 \text { weeks) }\end{array}$ & $\begin{array}{l}56 \% \\
(1 \%)\end{array}$ & $\begin{array}{l}52 \% \\
(12 \%)\end{array}$ & - & - \\
\hline $\begin{array}{l}\text { Certolizumab pegol }{ }^{34} \\
(400 \mathrm{mg} \text { at weeks } 0 \text { and } 2 \text { and then } 200 \mathrm{mg} \\
\text { every } 4 \text { weeks) }\end{array}$ & $\begin{array}{l}62 \% \\
(15 \%)\end{array}$ & $\begin{array}{l}64 \% \\
(24 \%)\end{array}$ & $\begin{array}{l}44 \% \\
(13 \%)\end{array}$ & $\begin{array}{l}28 \% \\
(4 \%)\end{array}$ \\
\hline $\begin{array}{l}\text { Ustekinumab }{ }^{36} \\
\text { ( } 45 \mathrm{mg} \text { at weeks } 0 \text { and } 4 \text { and then every } \\
12 \text { weeks) }\end{array}$ & $\begin{array}{l}57 \% \\
(11 \%)\end{array}$ & $\begin{array}{l}42 \% \\
(23 \%)\end{array}$ & $\begin{array}{l}25 \% \\
(9 \%)\end{array}$ & $\begin{array}{l}12 \% \\
(2 \%)\end{array}$ \\
\hline $\begin{array}{l}\text { Secukinumab }{ }^{40} \\
\text { ( } 150 \mathrm{mg} \text { at weeks } 0, \mathrm{I}, 2,3 \text {, and } 4 \text { and then } \\
\text { every } 4 \text { weeks) }\end{array}$ & $\begin{array}{l}48 \% \\
(16 \%)\end{array}$ & $\begin{array}{l}51 \% \\
(15 \%)\end{array}$ & $\begin{array}{l}35 \% \\
(7 \%)\end{array}$ & $\begin{array}{l}21 \% \\
(1 \%)\end{array}$ \\
\hline
\end{tabular}

Notes: The percentages within the brackets refer to the related placebo values. *At week I2. Data are only presented for an illustrative purpose but not for a direct comparison.

Abbreviations: PsA, psoriatic arthritis; PASI, Psoriasis Area and Severity Index; ACR, American College of Rheumatology improvement criteria. 
GOL is a fully humanized IgG1k anti-TNF- $\alpha$ given by monthly subcutaneous injection (50 mg every month). Its efficacy in PsA was assessed through GO-REVEAL trial showing a significant improvement of ACR 20 (GOL $100 \mathrm{mg}$ $61 \%$, GOL $50 \mathrm{mg} 52 \%$, placebo 12\%), PsARC (GOL $100 \mathrm{mg}$ $85 \%$, GOL $50 \mathrm{mg} 70 \%$, placebo 29\%), and PASI 75 (GOL

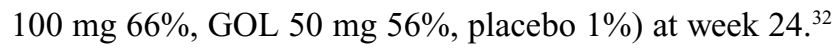
Significant improvement was observed for other major secondary endpoints including HAQ, 36-Item Short Form Health Survey (SF-36), Nail Psoriasis Severity Index, and PsA-modified Maastricht Ankylosing Spondylitis Enthesitis Score. GOL was generally well tolerated in this trial. ${ }^{32}$ Moreover, an inhibition of joint damage was observed in comparison with placebo at week $52 .{ }^{33}$

CZP is a humanized anti-TNF monoclonal antibody Fab fragment. Because lacking the Fc portion of the immunoglobulin, CZP does not induce any Fc- receptor-mediated immune effects such as complement or antibody-ependent cell-mediated cytotoxicity. It is able to neutralize membrane TNF- $\alpha$ monovalently rather than divalently. CZP is pegylated so that its half-life is longer (14 days) and stability and solubility are increased, whereas its immunogenicity is reduced. It is given subcutaneously with a starting dose of $400 \mathrm{mg}$ at weeks 0,2 , and 4 and then $200 \mathrm{mg}$ every other week. CZP efficacy in PsA has been evaluated through a multicentric, randomized, double-blind randomized controlled trial (RCT) (RAPID-PsA) showing a significant improvement in ACR 20 (CZP $400 \mathrm{mg}$ Q4W 56\%, CZP 200 mg Q2W 64\%, placebo 24\%), PASI 75 (CZP 400 mg Q4W 61\%, CZP 200 mg Q2W 62\%, placebo $15 \%$ ) and an improvement in disability and QoL measures at week 24. No differences in adverse events when compared to placebo were found. ${ }^{34}$ With regard to radiographic progression, at week 24 the mean change from baseline mTSS score was 0.06 in patients receiving $\mathrm{CZP}$ and 0.28 in those receiving placebo. ${ }^{35}$

UST is a fully human IgG1 monoclonal antibody that binds with high affinity to the shared p40 subunit of human IL-12 and IL-23, inhibiting their binding to the IL-12R $\beta 1$ receptor on the surface of T cells, NK cells, and antigenpresenting cells (APCs). Since 2009, it has been used for treating moderate-to-severe psoriasis, and it has been recently approved for PsA. It is given subcutaneously with a starting dose of $45 \mathrm{mg}$ (or $90 \mathrm{mg}$ if weight $>100 \mathrm{~kg}$ ) at weeks 0 and 4 and then $45 \mathrm{mg}$ every 12 weeks. Its safety and efficacy have been evaluated in 2 multicentric, double-blind, placebocontrolled trials (PSUMMIT 1 and PSUMMIT 2). ${ }^{36,37}$ The first trial enrolled patients naive to biological therapy, the second one also included patients who failed anti-TNF- $\alpha$ agents. TNF- $\alpha$ agents. At week 24 , there was a significant improvement in ACR 20 in PSUMMIT 1 (UST $90 \mathrm{mg} \mathrm{50 \% ,}$

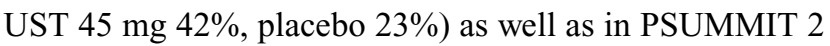
(UST $90 \mathrm{mg}$ 44\%, UST $45 \mathrm{mg}$ 44\%, placebo 20\%). A following study integrated data from PSUMMIT 1 and PSUMMIT 2 showing an inhibition of radiographic progression. ${ }^{38}$

SEC is a human monoclonal antibody targeted against IL-17A. Initially approved for psoriasis treatment, it has recently been approved for PsA. The efficacy of SEC in PsA has been investigated in 2 randomized, double-blind, placebo-controlled multinational phase III trials, FUTURE $1^{39}$ and FUTURE $2 .{ }^{40}$ In the first, SEC was given at beginning intravenously and then subcutaneously. In FUTURE 2, patients were treated with subcutaneous SEC since the beginning of trial. At week 24, both trials showed an improvement in ACR 20 (FUTURE 1, SEC $150 \mathrm{mg} \mathrm{50 \% ,} \mathrm{SEC} 75$ mg 50\%, placebo 17\%; FUTURE 2, SEC $300 \mathrm{mg} \mathrm{54 \% ,} \mathrm{SEC}$ $150 \mathrm{mg} 51 \%$, placebo 15\%), PASI 75 (FUTURE 1, SEC 150

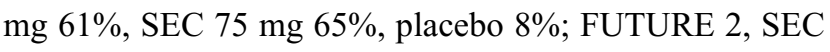

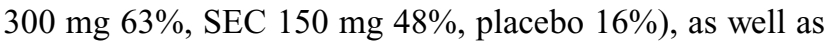
HAQ and SF-36. ${ }^{39,40}$ Pooled data (SEC 75, 150, and 300 $\mathrm{mg}$ ) from FUTURE 2 study showed resolution of dactylitis ( $47 \%$ vs $15 \%$ of placebo) and enthesitis ( $40 \%$ vs $22 \%$ of placebo). ${ }^{40} \mathrm{SEC}$ effects seemed to be greater in patients naive to other biological treatments. ${ }^{40}$ Radiological progression was considered only in FUTURE 1: at week 24, SEC-treated patients showed significantly less radiographic progression than placebo. ${ }^{39} \mathrm{SEC}$ was well tolerated, and the most common reported adverse events were mild to moderate, non-serious infections. Exacerbation of inflammatory bowel disease as well as new onset has been reported during treatment with SEC. Therefore, patients should be monitored for bowel signs and symptoms and caution should be exercised in patients with Crohn's disease. ${ }^{40}$

\section{Pharmacoeconomic issues and biosimilars}

Biosimilars to INF (CT-P13, Remsima and Inflectra) and ETN (SB4, Benepali) are currently licensed for PsA treatment.

Although their impact on rheumatic diseases has been remarkable, biological drugs are a very large financial burden for payers. Since a number of patents pertaining to certain biological drugs are expiring, there is a growing interest in developing biosimilar agents. However, it is expected that the decline of biological originator therapies will not be as strong as that given by the introduction of generics for brand synthetic drugs. ${ }^{41,42}$

According to the World Health Organization, a biosimilar is a "biotherapeutic product which is similar in terms of quality, safety, and efficacy to an already licensed reference 
biotherapeutic product". The FDA and the EMA agree that at least 1 adequately powered equivalence trial is necessary to demonstrate biosimilarity. Both the agencies indicate the importance of equivalence trial more than non-inferiority one, whereas a challenge remains how powerful an RCT should be to demonstrate safety. ${ }^{43,44}$

A challenge to consider is certainly the switch between an originator and a biosimilar, which is not regulated by any guidelines. Few data have emerged from literature and RCT, whereas several efforts are in progress to collect real-life data about transition. ${ }^{45}$ An example is the NOR-SWITCH study, a non-inferiority 12-month study aimed to evaluate the retention of efficacy, as well as the appearance of adverse events in a group of patients after transition from INF to CT-P13. Its preliminary results were recently published. ${ }^{46}$

PLANETAS is another study evaluating the appearance of adverse events in ankylosing spondylitis patients who remain in INF and those who transit to CT-P13. The rates of infusionrelated reactions seem to be similar (3.9\% for CT-P13 vs $4.9 \%$ for INF). ${ }^{47} \mathrm{RCT}$ s for biosimilars appear to be underpowered for identifying unexpected adverse events since they usually enroll fewer than 600 participants. For this reason, careful postmarking pharmacovigilance is particularly important. ${ }^{45}$

There are no studies to evaluate different clinical indications of biosimilars and, noteworthy, no data from RCTs enrolling PsA patients are currently available. No biosimilar is likely to be studied across all relevant diseases, provided they share the same mechanism of action. ${ }^{48}$

\section{Future drugs with different mechanisms of action}

Several drugs with different mechanisms of action (cytokine inhibitors/modulators, co-stimulatory molecule inhibitors, B-cell targeting agents, tyrosine kinase inhibitors) are under investigation for PsA. ${ }^{1,16}$

Among possible mechanisms of action for biological drugs in PsA, there is strong evidence that the CD8 $\mathrm{T}$ lymphocyte plays a pivotal role in PsA and this is also demonstrated by the response to therapeutic agents directed to $\mathrm{T}$ cells as well as to effector pathways resulting from T-cell activation. The full T-cell activation involves both the binding of the T-cell receptor to the antigen-MHC complex and a co-stimulatory signal from the binding of the T-cell CD28 protein to the B7 protein on the APCs. Abatacept prevents APCs from delivering the co-stimulatory signal to $\mathrm{T}$ cells. Studies evaluating the potential efficacy of abatacept in PsA are currently ongoing, while some case reports assessed its efficacy in PsA and other spondyloarthritis. ${ }^{49,50}$
B-cell targeting could be another treatment option in PsA, because some evidence showed B-cell lymphoid aggregates in PsA synovial tissue. ${ }^{51}$ The rationale of a possible usage of B-cell depleting agents is, therefore, supported by some pathogenetic mechanisms. Unfortunately, little data are at present available on the effect of these medications on PsA. Rituximab, an anti-CD20, B-cell depleting biological agent, showed modest effects on the musculoskeletal and cutaneous manifestations of psoriatic disease, confirming the secondary role of $\mathrm{B}$ cells in the pathogenesis of PsA.

Small molecule drugs are low molecular mass compounds that act by interrupting the intracellular signaling based on the inhibition of kinases. They are quite easy to synthesize, not so expensive, and orally bioavailable. Among them are Janus kinase inhibitors, tyrosine kinase inhibitors, as well as the p38 mitogen-activated protein kinase pathway inhibitors.

\section{Choice of biologicals}

All TNF- $\alpha$ blockers have been studied in RCTs and in observational postmarketing studies with consistent evidence supporting their safety and efficacy in PsA. ${ }^{12,13}$ A systematic review by Ash et al evaluated efficacy and safety of ADA, INF, GOL, and ETN. ${ }^{53}$ At 12-14 weeks, there were no significant differences in efficacy and safety among different anti-TNF- $\alpha$ agents and all the 4 drugs were significantly more effective than placebo for PsARC; ACR 20, 50, and 70 response criteria; and PASI as well as for dactylitis and enthesitis. Moreover, an improvement in QoL was observed. ${ }^{53}$ Similarly to that observed in rheumatoid arthritis, PsA safety data underline that TNF inhibitors can be associated with an increased infectious risk (bacterial, viral, fungal, and mycobacterial) requiring careful monitoring. ${ }^{54}$ Moreover, TNF- $\alpha$ blockers are the first drugs whose efficacy on radiographic progression has been clearly demonstrated. ${ }^{1}$ Anti-TNF- $\alpha$ drugs have been compared in a single randomized non-blinded study involving 100 patients with $\mathrm{PsA}^{55}$ and in 2 indirect comparison meta-analyses ${ }^{56,57}$ showing that significant differences in their effectiveness cannot be demonstrated.

To date, there is no RCT trial aimed to assess efficacy on manifestations different from peripheral joint involvement. Only 1 observational study reported on the effect of ETN in 32 patients with axial PsA showing, after a 12-month treatment, a significant improvement of Bath Ankylosing Spondylitis Disease Activity Index and Bath Ankylosing Spondylitis Functional Index. ${ }^{58}$ Dactylitis and enthesitis were evaluated as secondary endpoints in some RCTs on GOL and INF showing a significant improvement. ${ }^{1}$ 
Because of a substantial similarity in efficacy and safety among different anti-TNF- $\alpha$ drugs, the drug choice is taken considering specific safety issues, extra-articular manifestations, and patient's preference. Indicatively, in patients with bowel or eye involvement, a monoclonal antibody is preferred, whereas in those at risk of tuberculosis ETN is the safer option.

As previously discussed, PsA is a heterogeneous disease with several clinical manifestations. To assist the clinician in the management of PsA, treatment recommendations have been developed (EULAR, GRAPPA). ${ }^{12,13}$ In agreement with these, we can have different therapeutic approaches according to the predominant clinical manifestation being present:

1. In peripheral arthritis, biological therapy should be considered in patients with peripheral synovitis not responsive to NSAIDs and csDMARDs. Patients with monoarthritis or oligoarthritis should have also failed steroid injections. The choice of biological drug should be also taken into account when patient develops new erosions or worsening of preexisting erosions.

2. In psoriatic spondylitis and/or sacroiliitis, biological drugs should be taken into consideration in patients who failed NSAIDs. As for ankylosing spondylitis, there are no evidence of efficacy for csDMARDs on axial PsA.

3. In dactylitis, the biological should be started in patients who failed NSAIDs and csDMARDs as well as steroid injections.

4. In enthesitis, biological treatment should be considered in patients who failed NSAIDs and steroid injections.

\section{Biological switch}

Currently, there are very few data about therapy in case of antiTNF- $\alpha$ failure. With regard to switch from a TNF- $\alpha$ inhibitor to another in PsA, there are very poor data. ${ }^{59,60}$ However, in clinical practice, switching from an anti-TNF- $\alpha$ to another is a successful strategy. ${ }^{61}$ Gossec and Smolen, based on the EULAR and GRAPPA recommendations, suggest that every biological drug and/or csDMARDs can be used after biological failure. ${ }^{62}$ As for switch from an TNF inhibitor to another, it is currently accepted that patients who failed a previous anti TNF- $\alpha$ may successfully response to another. ${ }^{59-63}$ Moreover, patients with a good clinical and laboratory response but with radiological progression have to be switched to another biological agent or co-treated with a csDMARD. However, there is no evidence of increased efficacy of anti-TNF- $\alpha$ therapy by using csDMARDs, and studies results are quite in contrast on their effects on prolonging anti-TNF- $\alpha$ survival. ${ }^{64,65}$
With regard to switching to another mode of action, data are limited to SEC and UST trials. In these studies, response to the drug was considered both in patients naive to anti-TNF agents and in those who failed such treatment. Efficacy in anti-TNF failures has been tested in PSUMMIT $2^{37}$ for UST and in FUTURE $2^{40}$ for SEC. Both the trials confirm their efficacy both in TNF-naive patients and in those previously treated..$^{37,40}$

\section{Conclusion}

The PsA treatment scenario has completely changed with the introduction of biological agents, which are more effective than csDMARDs on symptoms and signs of the disease, improve function and QoL, and inhibit the structural damage in peripheral joints.

No evidence-based strategies are currently available for guiding the rheumatologist to prescribe biological drugs. A conservative approach should suggest their use after the failure of csDMARDs but early PsA may be treated with a delay making less useful the advantage of an early recognition of the disease. In authors' opinion, a more efficacious intervention with biological agents at an early stage, when tissue injury may still be reversible, could result in a great benefit for the patient. However, one of possible criticisms to this approach is the heterogeneous clinical spectrum of PsA, which includes self-limiting forms.

Several international and national recommendation sets are currently available with the aim to help rheumatologists in everyday clinical practice management of PsA patients treated with biological therapy. These treatment recommendations suggest that biological agents, preferentially TNF blockers, should be reserved for patients with active disease with different starting modalities according to the pattern of presentation of the psoriatic disease, i.e., peripheral arthritis, enthesitis, dactylitis, and axial disease.

To date, there are no direct head-to-head RCTs comparing biological agents. Since no specific biological agent has been demonstrated to be more effective than others, the drug choice should be made according to the available safety data, the presence of extra-articular manifestations, the patient's preferences (e.g., administration route), and the drug price. However, future studies directly comparing different biological drugs and assessing the efficacy of treatment strategies specific for PsA are urgently needed.

\section{Disclosure}

The authors report no conflicts of interest in this work. 


\section{References}

1. Olivieri I, D'Angelo S, Palazzi C, Padula A. Advances in the management of psoriatic arthritis. Nat Rev Rheumatol. 2014;10(9):531-542.

2. Scarpa R, Ayala F, Caporaso N, Olivieri I. Psoriasis, psoriatic arthritis, or psoriatic disease? J Rheumatol. 2006;33(2):210-212.

3. Gladman DD. Psoriatic arthritis. In: Harris ED Jr, Budd RC, Firestein GS, Genovese MC, Sergent JS, Ruddy S, Sledge CB, editors. Kelley's Textbook of Rheumatology. 7th ed. Philadelphia, PA: W.B. Saunders co.; 2004:1155-1164.

4. Scarpa R, Manguso F, D'Arienzo A, et al. Microscopic inflammatory changes in colon of patients with both active psoriasis and psoriatic arthritis without bowel symptom. J Rheumatol. 2000;27(5):1241-1246.

5. Queiro R, Torre JC, Belzunegui J, et al. Clinical features and predictive factors in psoriatic arthritis-related uveitis. Semin Arthritis Rheum. 2002;31(4):264-270.

6. Mallbris L, Ritchlin CT, Ståhle M. Metabolic disorders in patients with psoriasis and psoriatic arthritis. Curr Rheumatol Rep. 2006;8(5): 355-363.

7. Gladman DD, Farewell VT, Wong K, Husted J. Mortality studies in psoriatic arthritis: results from a single outpatient center. II. Prognostic indicators for death. Arthritis Rheum. 1998;41(6):1103-1110.

8. Gladman DD. Quality of life: psoriatic arthritis. In: Gordon KB, Ruderman EM, editors. Psoriasis and Psoriatic Arthritis: An Integrated Approach. Berlin, Heidelberg: Springer-Verlag; 2005:118-123.

9. McHugh NJ, Balachrishnan C, Jones SM. Progression of peripheral joint disease in psoriatic arthritis: a 5-yr prospective study. Rheumatology (Oxford). 2003;42(6):778-783.

10. Olivieri I, D'Angelo S, Padula A, Palazzi C. The challenge of early diagnosis of psoriatic arthritis. J Rheumatol. 2008;35(1):3-5.

11. Scarpa R, Atteno M, Lubrano E, et al. The effectiveness and safety of TNF-alpha blockers in the treatment of early psoriatic arthritis: an Italian multicenter longitudinal observational pilot study. Clin Rheumatol. 2011;30(8):1063-1067.

12. Coates LC, Kavanaugh A, Mease PJ, et al. Group for research and assessment of psoriasis and psoriatic arthritis 2015 treatment recommendations for psoriatic arthritis. Arthritis Rheumatol. 2016;68(5):1060-1071.

13. Gossec L, Smolen JS, Ramiro S, et al. European League Against Rheumatism (EULAR) recommendations for the management of psoriatic arthritis with pharmacological therapies: 2015 update. Ann Rheum Dis 2016;75(3):499-510.

14. D’Angelo S, Palazzi C, Olivieri I. Psoriatic arthritis: treatment strategies using biologic agents. Reumatismo. 2012;64:113-121.

15. Coates LC, Moverley AR, McParland L, et al. Effect of tight control of inflammation in early psoriatic arthritis (TICOPA): a UK multicentre, open-label, randomised controlled trial. Lancet. 2015;386(10012): 2489-2498.

16. Olivieri I, D’Angelo S, Palazzi C, Lubrano E, Leccese P. Emerging drugs for psoriatic arthritis. Expert Opin Emerg Drugs. 2010;15(3):399-414.

17. Schafer P. Apremilast mechanism of action and application to psoriasis and psoriatic arthritis. Biochem Pharmacol. 2012;83(12):1583-1590.

18. Schett G, Wollenhaupt J, Papp K, et al. Oral apremilast in the treatment of active psoriatic arthritis: results of a multicenter, randomized, double-blind, placebo-controlled study. Arthritis Rheum. 2012;64(10): 3156-3167.

19. Kavanaugh A, Mease PJ, Gomez-Reino JJ, et al. Treatment of psoriatic arthritis in a phase 3 randomised, placebo-controlled trial with apremilast, an oral phosphodiesterase 4 inhibitor. Ann Rheum Dis. 2014; 73:1020-1026.

20. Cutolo M, Myerson GE, Fleischmann RM, et al. A phase III, randomized, controlled trial of apremilast in patients with psoriatic arthritis: results of the PALACE 2 trial. J Rheumatol. 2016;43(9):1724-1734.

21. Edwards CJ, Blanco FJ, Crowley J, et al. Apremilast, an oral phosphodiesterase 4 inhibitor, in patients with psoriatic arthritis and current skin involvement: a phase III, randomised, controlled trial (PALACE 3). Ann Rheum Dis. 2016;75(6):1065-1073.
22. Wells AF, Edwards CJ, Adebajo AO, et al. Apremilast in the treatment of DMARD-naive psoriatic arthritis patients: results of a phase 3 randomized, controlled trial (PALACE 4). Arthritis Rheum. 2013;65(12): 3320-3321.

23. Antoni C, Krueger GG, de Vlam K, et al; IMPACT 2 Trial Investigators. Infliximab improves signs and symptoms of psoriatic arthritis: results of the IMPACT 2 trial. Ann Rheum Dis. 2005;64(8):1150-1157.

24. Antoni CE, Kavanaugh A, van der Heijde D, et al. Two-year efficacy and safety of infliximab treatment in patients with active psoriatic arthritis: findings of the Infliximab Multinational Psoriatic Arthritis Controlled Trial (IMPACT). J Rheumatol. 2008;35(5):869-876.

25. van der Heijde D, Kavanaugh A, Gladman DD, et al. Infliximab inhibits progression of radiographic damage in patients with active psoriatic arthritis through one year of treatment: results from the induction and maintenance psoriatic arthritis clinical trial 2. Arthritis Rheum. 2007;56(8): 2698-2707.

26. Mease PJ, Kivitz AJ, Burch FX, et al. Etanercept treatment of psoriatic arthritis: safety, efficacy, and effect on disease progression. Arthritis Rheum. 2004;50(7):2264-2272.

27. Palazzi C, D'Angelo S, Cantini F, et al. Etanercept in spondyloarthropathies. Part I: current evidence of efficacy. Clin Exp Rheumatol. 2011;29(5):858-864.

28. D'Angelo S, Palazzi C, Cantini F, et al. Etanercept in spondyloarthropathies. Part II: safety and pharmacoeconomic issues. Clin Exp Rheumatol. 2011;29(5):865-870.

29. Mease PJ, Gladman DD, Ritchlin CT, et al. Adalimumab for the treatment of patients with moderately to severely active psoriatic arthritis: results of a double-blind, randomized, placebo-controlled trial. Arthritis Rheum. 2005;52(10):3279-3289.

30. Mease PJ, Ory P, Sharp JT, et al. Adalimumab for long-term treatment of psoriatic arthritis: 2-year data from the Adalimumab Effectiveness in Psoriatic Arthritis Trial (ADEPT). Ann Rheum Dis. 2009;68(5):702-709.

31. Gladman DD, Mease PJ, Ritchlin CT, et al. Adalimumab for long-term treatment of psoriatic arthritis: forty-eight week data from the adalimumab effectiveness in psoriatic arthritis trial. Arthritis Rheum. 2007; 56(2):476-488.

32. Kavanaugh A, McInnes I, Mease P, et al. Golimumab, a new human tumor necrosis factor alpha antibody, administered every four weeks as a subcutaneous injection in psoriatic arthritis: twenty-four-week efficacy and safety results of a randomized, placebo-controlled study. Arthritis Rheum. 2009;60(4):976-986.

33. Kavanaugh A, van der Heijde D, McInnes IB, et al. Golimumab in psoriatic arthritis: one-year clinical efficacy, radiographic, and safety results from a phase III, randomized, placebo-controlled trial. Arthritis Rheum. 2012;64(8):2504-2517.

34. Mease PJ, Fleischmann R, Deodhar AA, et al. Effect of certolizumab pegol on signs and symptoms in patients with psoriatic arthritis: 24-week results of a Phase 3 double-blind randomised placebo-controlled study (RAPID-PsA). Ann Rheum Dis. 2014;73(1):48-55.

35. van der Heijde D, Fleischmann R, Wollenhaupt J, et al. Effect of different imputation approaches on the evaluation of radiographic progression in patients with psoriatic arthritis: results of the RAPID-PsA 24-week phase III double-blind randomised placebo-controlled study of certolizumab pegol. Ann Rheum Dis. 2014;73(1):233-237.

36. McInnes IB, Kavanaugh A, Gottlieb AB, et al; PSUMMIT 1 Study Group. Efficacy and safety of ustekinumab in patients with active psoriatic arthritis: 1 year results of the phase 3, multicentre, doubleblind, placebo-controlled PSUMMIT 1 trial. Lancet. 2013;382(9894): 780-789.

37. Ritchlin C, Rahman P, Kavanaugh A, et al; PSUMMIT 2 Study Group. Efficacy and safety of the anti-IL-12/23 p40 monoclonal antibody, ustekinumab, in patients with active psoriatic arthritis despite conventional non-biological and biological anti-tumour necrosis factor therapy: 6-month and 1-year results of the phase 3, multicentre, double-blind, placebo-controlled, randomised PSUMMIT 2 trial. Ann Rheum Dis. 2014;73(6):990-999. 
38. Kavanaugh A, Ritchlin C, Rahman P, et al; PSUMMIT-1 and 2 Study Groups. Ustekinumab, an anti-IL-12/23 p40 monoclonal antibody, inhibits radiographic progression in patients with active psoriatic arthritis: results of an integrated analysis of radiographic data from the phase 3, multicentre, randomised, double-blind, placebo-controlled PSUMMIT-1 and PSUMMIT-2 trials. Ann Rheum Dis. 2014;73(6): 1000-1006.

39. Mease PJ, McInnes IB, Kirkham B, et al; FUTURE 1 Study Group. Secukinumab inhibition of interleukin-17A in patients with psoriatic arthritis. N Engl J Med. 2015;373(14):1329-1339.

40. McInnes IB, Mease PJ, Kirkham B, et al; FUTURE 2 Study Group. Secukinumab, a human anti-interleukin-17A monoclonal antibody, in patients with psoriatic arthritis (FUTURE 2): a randomised, doubleblind, placebo-controlled, phase 3 trial. Lancet. 2015;386(9999): 1137-1146.

41. Strand V, Cronstein B. Biosimilar: how similar? Intern Med J. 2014; 44(3):218-223.

42. Mestre-Ferrandiz J, Towse A, Berdud M. Biosimilars: how can payers get long-term savings? Pharmacoeconomics. 2016;34(6):609-616.

43. Reichert JM, Beck A, Iyer H. European Medicines Agency workshop on biosimilar monoclonal antibodies: July 2, 2009, London, UK. MAbs. 2009;1(5):394-416.

44. Dörner T, Strand V, Cornes P, et al. The changing landscape of biosimilars in rheumatology. Ann Rheum Dis. 2016;75(6):974-982.

45. Dörner T, Kay J. Biosimilars in rheumatology: current perspectives and lessons learnt. Nat Rev Rheumatol. 2015;11(12):713-724.

46. Goll GL, Olsen IC, Jorgensen KK, et al. Biosimilar infliximab (CT$\mathrm{P} 13$ ) is not inferior to originator infliximab: results from a 52-week randomized switch trial in Norway [abstract]. Arthritis Rheumatol. 2016;68(Suppl 10).

47. Park W, Hrycaj P, Jeka S, et al. A randomised, double-blind, multicentre, parallel-group, prospective study comparing the pharmacokinetics, safety, and efficacy of CT-P13 and innovator infliximab in patients with ankylosing spondylitis: the PLANETAS study. Ann Rheum Dis. 2013; 72(10):1605-1612.

48. Weise M, Kurki P, Wolff-Holz E, Bielsky MC, Schneider CK. Biosimilars: the science of extrapolation. Blood. 2014;124(22):3191-3196.

49. Mease P, Genovese MC, Gladstein G, et al. Abatacept in the treatment of patients with psoriatic arthritis: results of a six-month, multicenter, randomized, double-blind, placebo-controlled, phase II trial. Arthritis Rheum. 2011;63(4):939-948.

50. Westhovens R, Verschueren P. Translating co-stimulation blockade into clinical practice. Arthritis Res Ther. 2008;10(Suppl 1):S4.

51. Cañete JD, Santiago B, Cantaert T, et al. Ectopic lymphoid neogenesis in psoriatic arthritis. Ann Rheum Dis. 2007;66(6):720-726.

52. Jimenez-Boj E, Stamm TA, Sadlonova M, et al. Rituximab in psoriatic arthritis: an exploratory evaluation. Ann Rheum Dis. 2012;71(11): $1868-1871$.
53. Ash Z, Gaujoux-Viala C, Gossec L, et al. A systematic literature review of drug therapies for the treatment of psoriatic arthritis: current evidence and meta-analysis informing the EULAR recommendations for the management of psoriatic arthritis. Ann Rheum Dis. 2012;71(3):319-326.

54. Saad AA, Hyrich KL, Ashcroft DM. Drug persistence, effectiveness and safety assessment of anti-TNF therapies in psoriatic arthritis. Expert Opin Drug Saf. 2011;10(2):219-226.

55. Atteno M, Peluso R, Costa L, et al. Comparison of effectiveness and safety of infliximab, etanercept, and adalimumab in psoriatic arthritis patients who experienced an inadequate response to previous diseasemodifying antirheumatic drugs. Clin Rheumatol. 2010;29(4):399-403.

56. Fénix-Caballero,Alegre-del Rey EJ, Castaño-Lara R, Puigventós-Latorre F, Borrero-Rubio JM, López-Vallejo JF. Direct and indirect comparison of the efficacy and safety of adalimumab, etanercept, infliximab and golimumab in psoriatic arthritis. J Clin Pharm Ther. 2013;38(4):286-293.

57. Thorlund K, Druyts E, Aviña-Zubieta JA, Mills EJ. Anti-tumor necrosis factor (TNF) drugs for the treatment of psoriatic arthritis: an indirect comparison meta-analysis. Biologics. 2012;6:417-427.

58. Lubrano E, Spadaro A, Marchesoni A, et al. The effectiveness of a biologic agent on axial manifestations of psoriatic arthritis. A twelve months observational study in a group of patients treated with etanercept. Clin Exp Rheumatol. 2011;29(1):80-84.

59. Delaunay C, Farrenq V, Marini-Portugal A, Cohen JD, Chevalier X, Claudepierre P. Infliximab to etanercept switch in patients with spondyloarthropathies and psoriatic arthritis: preliminary data. JRheumatol. 2005;32(11):2183-2185.

60. SaadAA, Ashcroft DM, Watson KD, Hyrich KL, Noyce PR, Symmons DP; British Society for Rheumatology Biologics Register. Persistence with anti-tumour necrosis factor therapies in patients with psoriatic arthritis: observational study from the British Society of Rheumatology Biologics Register. Arthritis Res Ther. 2009;11(2):R52.

61. Glintborg B, Ostergaard M, Krogh NS, et al. Clinical response, drug survival, and predictors thereof among 548 patients with psoriatic arthritis who switched tumor necrosis factor $\alpha$ inhibitor therapy: results from the Danish Nationwide DANBIO Registry. Arthritis Rheum. 2013; 65(5):1213-1223.

62. Gossec L, Smolen JS. Treatment of psoriatic arthritis: management recommendations. Clin Exp Rheumatol. 2015;33(5 Suppl 93):S73-S77.

63. Olivieri I, Scarano E, Padula A, D'angelo S, Cantini F. Switching tumor necrosis factor alpha inhibitors in HLA-B27-associated severe heel enthesitis. Arthritis Rheum. 2007;57(8):1572-1574.

64. Kristensen LE, Gülfe A, Saxne T, Geborek P. Efficacy and tolerability of anti-tumour necrosis factor therapy in psoriatic arthritis patients: results from the South Swedish Arthritis Treatment Group register. Ann Rheum Dis. 2008;67(3):364-369.

65. Spadaro A, Ceccarelli F, Scrivo R, Valesini G. Life-table analysis of etanercept with or without methotrexate in patients with psoriatic arthritis. Ann Rheum Dis. 2008;67(11):1650-1651.
Open Access Rheumatology: Research and Reviews

\section{Publish your work in this journal}

Open Access Rheumatology: Research and Reviews is an international, peerreviewed, open access journal publishing original research, reports, editorials, reviews and commentaries on all aspects of clinical and experimental rheumatology in the clinic and laboratory including the following topics: Pathology, pathophysiology of rheumatological diseases; Investigation, treatment and management of rheumatological diseases; Clinical trials and novel pharmacologi$\mathrm{cal}$ approaches for the treatment of rheumatological disorders. The manuscript management system is completely online and includes a very quick and fair peer-review system, which is all easy to use. Visit http://www.dovepress.com/ testimonials.php to read real quotes from published authors. 